\title{
The effects of calcium and sodium loading on organic matter digestibility and mineral absorption in sheep \\ 1. Digestion in the forestomachs and small intestine
}

\author{
Hanna Leontowicz, R. Krzemiński, Maria Leontowicz, \\ G. Kulasek, M. Gralak and Violetta Leśniewska
}

\author{
Department of Animal Physiology, Warsaw Agricultural University \\ Nowoursynowska 166, 02-766 Warsaw, Poland
}

(Received 8 March 1995; accepted 6 November 1995)

\begin{abstract}
Experiments were conducted on sheep cannulated to the rumen, duodenum and ileum to study the effects of $\mathrm{Ca}$ and $\mathrm{Na}$ loading (5 and 10 times the $\mathrm{ARC}$ requirements) on digestion in the rumen and intestines. The introduction of calcium lactate $(19.6 \%)$ or sodium chloride $(9.6 \%)$ into extruded feed mixtures had no significant effect on degradation in the rumen (apparent digestibility of organic matter in the forestomachs averaged $40 \%$, ileal digestibility $61 \%$ ) or on the $\mathrm{pH}$ of ruminal (5.73), duodenal (3.37) or ileal (7.63) digesta. Excess sodium in the diet reduced $(\mathbf{P}<0.05)$ microbial protein synthesis in the rumen (7.69g N-MP/d) in comparison with control sheep and those loaded with $\mathrm{Ca}$ (10.46 and $10.74 \mathrm{~g} \mathrm{~N}-\mathrm{MP} / \mathrm{g}$ ) as well as the apparent digestibility of total nitrogen in the small intestine.
\end{abstract}

KEY WORDS: $\mathrm{Ca}, \mathrm{Na}$, sheep, digestion, protein synthesis

\section{INTRODUCTION}

Fibrous feeds are often treated with calcium or sodium alkali in order to improve their digestibility in ruminants, while rations containing large amounts of starch are fed along with calcium-containing buffers. However, these processes also lead to loading with $\mathrm{Na}$ and $\mathrm{Ca}$ (Lukomski, 1980). A high calcium and sodium content in the diet of ruminants can reduce feed intake and utilization (Wilson and Dudziński, 1973; Goodrich et al., 1985) and the digestibility of organic matter (Hemsley, 1975; Jacobson et al., 1975; Gralak et al., 1994). Changes in the concentration of mineral components in the digestive 
tract, including $\mathrm{Ca}$ and $\mathrm{Na}$, can change digesta pH (Rogers et al., 1982), cellulolytic activity (van Soest, 1982; Harris et al., 1989) and microbial protein synthesis in the rumen (Durland and Kawashima, 1980; Leontowicz et al., 1994).

The objective of this study was to assess the effect of rations containing excess calcium and sodium (5 and 10 times more, respectively, than ARC requirements) on ruminal and intestinal digestion dynamics and ruminal microbial protein synthesis in sheep.

\section{MATERIAL AND METHODS}

\section{Animals}

The study was carried out on 9 Merino wethers with an average initial body weight of $24 \pm 1.5 \mathrm{~kg}$. The sheep were divided into 3 groups: control (I), calcium-loaded (II; $20 \%$ calcium lactate) and sodium-loaded (III; $8.5 \% \mathrm{NaCl}$ in the ration). The calcium content in the diet fed group II was 5 times, while that of sodium in group III, 10 times higher than given in the ARC requirements (1980). The sheep received extruded concentrate mixtures (Table 1) and chopped meadow hay at a proportion of $1: 1$.

All of the sheep were cannulated with a Jarett cannula to the rumen, a straight $\mathrm{T}$ cannula (PVC) to the duodenum $(2-3 \mathrm{~cm}$ after the pancreatic-bile duct orifice) and to the ileum ( $7 \mathrm{~cm}$ before the appendix).

\section{Experimental design}

The experiment has started with a 3-week adaptation period and 2-week period of digesta collection. The sheep were fed 3 times daily; extruded mixtures $(0.4 \mathrm{~kg} / \mathrm{animal} / \mathrm{day})$ at $9 \mathrm{~h}$, followed an hour later by $1 / 2$ of the hay ration and the remainder at $16 \mathrm{~h}$. The animals were watered twice daily at 8 and $15 \mathrm{~h}$. Feed and water intake were controled. Chromium in the form of chromic oxide impregnated paper was given twice daily through the cannula to the rumen 4 days before collection and throughout the collection period at a dose of $1.64 \mathrm{~g} \mathrm{Cr}_{2} \mathrm{O}_{3} / \mathrm{d}$.

\section{Sample collection and chemical analysis}

Duodenal and ileal digesta were collected on days 1 and 2 of the fourth and fifth week of the experiment for the first $48 \mathrm{~h}$ in 6 -h intervals. The $\mathrm{pH}$ was measured in each digesta sample, after which they were mixed and the unfiltered samples were pooled to obtain daily samples for dry matter (DM), total nitrogen and ammonia determination. The remaining part of the digesta sampled from the 
TABLF: 1

Composition and nutritional value of concentrates for sheep, $\mathrm{g} / \mathrm{kg}$

\begin{tabular}{|c|c|c|c|}
\hline \multirow[b]{2}{*}{ Ingredients, $\mathrm{g} / \mathrm{kg}$} & \multicolumn{3}{|c|}{ Concentrates } \\
\hline & $\begin{array}{c}\text { I } \\
\text { control }\end{array}$ & $\begin{array}{c}\text { II } \\
\text { Ca-loading }\end{array}$ & $\begin{array}{c}\text { III } \\
\text { Na-loading }\end{array}$ \\
\hline Barley & 680 & 554 & 600 \\
\hline Soyabean meal & 219 & 195 & 215 \\
\hline Fodder yeast & 25 & 20 & 24 \\
\hline Polfamix D & 25 & 25 & 25 \\
\hline Calcium lactate & 50 & 196 & 50 \\
\hline Urea & - & 9 & - \\
\hline Sulphur' & 1 & 1 & 1 \\
\hline $\mathrm{NaCl}$ & - & - & 85 \\
\hline \multicolumn{4}{|l|}{ Per kg feed } \\
\hline dry mattcr, $g$ & 875.3 & 888.4 & 878.5 \\
\hline metabolic encrgy, ${ }^{2} \mathrm{MJ}$ & 10.7 & 10.5 & 9.7 \\
\hline RDP, $g^{3}$ & 92.0 & 95.0 & 83.5 \\
\hline UDP, $\mathrm{g}$ & 68.1 & 52.6 & 62.2 \\
\hline
\end{tabular}

${ }_{1}$ sulphur was supplied as a $1: 1$ proportion of $\mathrm{Na}_{2} \mathrm{SO}_{4}$ and elemental sulphur

${ }^{2}$ the metabolic energy content of the ration was calculated using the regression coefficient for sheep according to van Es (1978)

${ }^{3}$ the RDP and UDP contents in the feed rations were calculated according to the ARC (1980) based on the determined crude protein content in the individual components of concentrates and hay

duodenum and ileum was frozen and pooled into daily samples after freeze-drying. $\mathrm{DM}$ was determined at $105^{\circ} \mathrm{C}$, ash, chromium according to Schürch et al. (1950) and total nitrogen was determined by the Kjeldahl (Kjeltec-Tecator) method in these samples. Nucleic acids were determined in duodenal digesta (Zinn and Owens, 1982).

On the third day of weeks four and five of the experiment the rumen content was sampled before and 1,2, 3, 4, 5 and $6 \mathrm{~h}$ after morning feeding. The $\mathrm{pH}$ was determined in all rumen samples, and the following in selected samples $(0,1$ and 3 hours): ammonia by the phenol reagent method, volatile fatty acids (VFA) by gas chromatography (Ziołecki and Kwiatkowska, 1973) and lactic acid (+) (Boehringer test kit).

\section{Calculations}

The apparent digestibility of DM and organic matter (OM) in the rumen and small intestine and their duodenal and ileal flows were calculated on the basis of the chromium content of the digesta from these two sites, using the formula given by Ruszczyc (1983). Microbial protein synthesis (MP) in the rumen was determined according to Czerkawski (1976) on the basis of duodenal nucleic acid flow. 
The results analyzed statistically by two-way variance analysis using Statgrafics software, while the difference between means was evaluated by the Tukey test.

\section{RESULTS}

The chemical composition of extruded feed mixtures and hay is given in Table 2. The sheep consumed all of the offered concentrates, while leaving some of the hay (expressed in \% of DM): 27.0, 6.3 and 12.9 in groups I, II and III, respectively. The animals fed the Ca ration consumed more DM $(\mathrm{P}<0.05)$ than controls (Table 3). Water intake in groups I-III equalled 2577, 2765 and $3455 \mathrm{ml} / \mathrm{d}(\mathrm{P}<0.05)$.

Chemical composition of feeds, $\mathrm{g} / \mathrm{kg} \mathrm{DM}$

TABLE 2

\begin{tabular}{lcccc}
\hline & \multicolumn{3}{c}{ Extruded concentrate } & \\
\cline { 2 - 4 } Nutrients & I & II & Meadow hay \\
& control & Ca-loading & Na-loading & \\
\hline Crude protein & 210 & 203 & 199 & 106 \\
Crude fibre & 40 & 35 & 33 & 330 \\
Fat & 21 & 24 & 19 & 40 \\
Ash & 54 & 149 & 170 & 82 \\
N-free extractives & 675 & 589 & 579 & 442 \\
Calcium & 8.0 & 45.3 & 14.5 & 6.7 \\
Sodium & 1.1 & 3.3 & 30.09 & 1.2 \\
\hline
\end{tabular}

TABLE 3

Digestibility of dry matter and organic matter in the forestomachs and small intestine of sheep $(\mathrm{x} \pm \mathrm{SD} ; \mathrm{n}=12=3$ sheep $\times 2$ samples $\mathrm{x} 2$ collections)

\begin{tabular}{|c|c|c|c|}
\hline \multirow[b]{2}{*}{ Inidices } & \multicolumn{3}{|c|}{ Group } \\
\hline & $\begin{array}{c}\text { I } \\
\text { control }\end{array}$ & $\begin{array}{c}\text { II } \\
\text { Ca-loading }\end{array}$ & $\begin{array}{c}\text { III } \\
\text { Na-loading }\end{array}$ \\
\hline DM intake, $g / d$ & $651 \pm 63^{a}$ & $725 \pm 26^{\mathrm{b}}$ & $704 \pm 70^{\mathrm{ab}}$ \\
\hline $\begin{array}{l}\text { forestomachs }^{1} \\
\text { small intestine } \\
\text { forestomachs }+ \text { small intestine }\end{array}$ & $\begin{array}{l}29.8 \pm 11.4 \\
27.7 \pm 9.5 \\
57.5 \pm 12.7\end{array}$ & $\begin{array}{l}\text { DM digesti } \\
29.1 \pm 11.0 \\
23.7 \pm 11.2 \\
52.8 \pm 7.80\end{array}$ & $\begin{array}{l}39.8 \pm 8.3 \\
22.2 \pm 5.5 \\
60.2 \pm 7.6\end{array}$ \\
\hline $\mathrm{OM}$ intake, $\mathrm{g} / \mathrm{d}$ & $608 \pm 58$ & $635 \pm 24$ & $617 \pm 64$ \\
\hline $\begin{array}{l}\text { forestomachs } \\
\text { small intestine } \\
\text { forestomachs }+ \text { small intestine }\end{array}$ & $\begin{array}{l}38.4 \pm 10.2 \\
23.3 \pm 9.1 \\
61.7 \pm 11.7\end{array}$ & $\begin{array}{l}\text { OM digesti } \\
35.7 \pm 10.6 \\
22.4 \pm 9.6 \\
58.1 \pm 7.1\end{array}$ & $\begin{array}{l}45.4 \pm 7.6 \\
18.4 \pm 6.5 \\
63.8 \pm 7.4\end{array}$ \\
\hline
\end{tabular}

$\mathrm{a}, \mathrm{b}-\mathrm{P}<0.05$

${ }^{1}$ forestomachs $=$ intake minus duodenum

${ }^{3}$ forestomachs + small intestine $=$ intake minus ileum

${ }^{2}$ small intestine $=$ duodenum minus ileum 
The highest $\mathrm{pH}$ value of rumen digesta (6.90) was found before feeding and differed $(\mathrm{P}<0.05)$ from the remaining values; they were lowest between 2 and $3 \mathrm{~h}$ (5.29-5.33). No significant differences were noted, however, in $\mathrm{pH}$ values among groups (Table 4 ). The ammonia content in the rumen of animals receiving $20 \%$ calcium lactate in their feed was higher $(\mathrm{P}<0.05)$ than in the control and sodium groups. The intensity of fermentation, expressed as the concentration of VFA and lactic acid, was similar in the rumen of all of the sheep, and the molar ratios of $\mathrm{C}_{2}: \mathrm{C}_{3}: \mathrm{C}_{4}$ did not differ significantly among groups (Table 4 ).

The $\mathrm{pH}$ of the duodenal content ranged from 3.3 (I) to 3.43 (II), while that of the ileum from 7.61 to 7.65 (Table 4). The timing of sampling did not influence the $\mathrm{pH}$ of the duodenal content. The $\mathrm{pH}$ of the ileum was significantly higher before feeding in all groups $(\mathrm{P}<0.05 ; 7.84)$ than in the successive samples during the day $(7.58,7.64,7.48)$.

Table 3 gives the apparent digestibility coefficients for DM and OM in the studied parts of the digestive tract, i.e. in the forestomachs (intake minus duodenal flow), the small intestine (duodenal minus ileal) and overall in the forestomach plus small intestine (intake minus ileal flow). DM apparent digestibility coefficients did not differ among groups and averaged 33, 25 and $57 \%$ in the forestomachs, small intestine and in the forestomachs + small intestine, respectively. The apparent digestibility coefficients of $\mathrm{OM}$ averaged $40 \%$ in the forestomachs, $21 \%$ in the small intestine and $61 \%$ in the forestomachs + small intestine.

TABLE 4

The $\mathrm{pH}$ of ruminal and intestinal digesta, ammonia, VFA and lactic acid concentrations in ruminal fluid in sheep ( $\mathrm{x} \pm \mathrm{SD} ; \mathrm{n}=18=3$ sheep $\mathrm{x} 2$ days collection $\times 3$ samples)

\begin{tabular}{lccc}
\hline & \multicolumn{3}{c}{ Group } \\
\cline { 2 - 4 } Indices & $\begin{array}{c}\text { I } \\
\text { control }\end{array}$ & $\begin{array}{c}\text { II } \\
\text { Ca-loading }\end{array}$ & $\begin{array}{c}\text { III } \\
\text { Na-loading }\end{array}$ \\
\hline pH & $5.59 \pm 0.63$ & $5.85 \pm 0.68$ & $5.74 \pm 0.61$ \\
Ammonia, mmol/1 & $1.2 \pm 0.9^{\text {at }}$ & $9.4 \pm 6.2^{\mathrm{b}}$ & $1.2 \pm 0.7^{\mathrm{a}}$ \\
LKT, mmol/1 & $114.6 \pm 14.0$ & $118.8 \pm 13.0$ & $116.4 \pm 12.9$ \\
Acetic acid, mmol/1 & $59.7 \pm 17.6$ & $66.5 \pm 18.1$ & $62.3 \pm 16.8$ \\
Propionic acid, mmol/1 & $37.2 \pm 5.2$ & $34.7 \pm 7.0$ & $35.8 \pm 4.4$ \\
Butyric acid, mmol/l & $13.5 \pm 2.9$ & $13.9 \pm 3.7$ & $14.6 \pm 4.1$ \\
Other VFA, mmol/l & $4.2 \pm 1.7$ & $3.8 \pm 1.9$ & $3.7 \pm 1.3$ \\
Lactic acid mmol/1 & $4.2 \pm 2.8$ & $3.9 \pm 3.0$ & $3.2 \pm 2.9$ \\
Duodenal pH & $3.33 \pm 0.37$ & $3.34 \pm 0.39$ & $3.35 \pm 0.41$ \\
Ileal $\mathrm{pH}^{2}$ & $7.65 \pm 0.25$ & $7.62 \pm 0.29$ & $7.64 \pm 0.23$ \\
\hline
\end{tabular}

$\mathrm{a}, \mathrm{b}-\mathrm{P}<0.05$

$\mathrm{n}=36=3$ sheep $\times 6$ samples $\times 2$ collections

${ }^{2} \mathrm{n}=24=3$ sheep $\times 4$ samples $\times 2$ collections 
Total nitrogen intake was similar in all groups, while its flow through the duodenum and ileum (expressed in per cent of intakc) did not differ among groups, although in sheep loaded with $\mathrm{Ca}$ and $\mathrm{Na}$ it was somewhat lower than in the control group (Table 5).

$\mathrm{NaCl}$ lowered $(\mathrm{P}<0.05)$ duodenal nucleic acid- $\mathrm{N}$ flow; ruminal microbial protein synthesis calculated on the basis of this flow was lower in group III loaded with $\mathrm{Na}(7.7 \mathrm{~g} \mathrm{~N}-\mathrm{MP} / \mathrm{d})$ than in groups I and II (10.46 and $10.74 \mathrm{~g}$ $\mathrm{N}-\mathrm{MP} / \mathrm{d}$, respectively) (Table 5). Excess $\mathrm{Na}$ in the diet reduced the digestibility of total $\mathrm{N}$ in the small intestine $(\mathrm{P}<0.05)$. Loading sheep with $\mathrm{Ca}$ and $\mathrm{Na}$ did not significantly affect absorption of total nitrogen in the small intestine, calculated in relation to the amount of nitrogen reaching the duodenum, which equaled 67 (II) to $69 \%$ (I) (Table 5).

\section{DISCUSSION}

Sheep receiving calcium lactate consumed more DM $(P<0.05)$ (Table 3$)$, which could be related to the reduced energy concentration in a diet containing large amounts of $\mathrm{Ca}(19 \mathrm{~g} / \mathrm{d})$ (Table 1). A similar relationship, although statistically insignificant, was observed in sheep loaded with sodium chloride (12 $\mathrm{g} \mathrm{NaCl} / \mathrm{d}$ ). Ruminants loaded with $\mathrm{Na}$ usually consume more water, as this is necessary to maintain electrolyte balance when the rumen is hypertonic and to support increased salivation in order to buffer the ruminal contents (Lukomski, 1980; Reffett and Boiling, 1985; Chiy and Phillips, 1993). In our study, water intake by sheep loaded with $\mathrm{Na}$ was $34 \%$ higher than in controls. Rogers et al.

TABLE 5

Nitrogen and nucleic acid flow in the duodenum, total- $\mathrm{N}$ digestibility and absorption in the small intestine of sheep ( $\mathrm{x} \pm \mathrm{SD} ; \mathrm{n}=12=3$ sheep $\times 2$ samples $\times 2$ collections)

\begin{tabular}{lccc}
\hline & \multicolumn{3}{c}{ Group } \\
\cline { 2 - 4 } Indices & $\begin{array}{c}\text { I } \\
\text { control }\end{array}$ & $\begin{array}{c}\text { II } \\
\text { Ca-loading }\end{array}$ & $\begin{array}{c}\text { III } \\
\text { Na-loading }\end{array}$ \\
\hline N itakc, g/d & $17.4 \pm 1.06$ & $18.2 \pm 0.4$ & $17.7 \pm 1.1$ \\
N flow, \% of intake & & & \\
$\quad$ duodenum & $139.7 \pm 24.4$ & $119.6 \pm 21.3$ & $119.0 \pm 16.1$ \\
$\quad$ ileum & $43.5 \pm 13.4$ & $38.8 \pm 6.5$ & $39.5 \pm 8.3$ \\
N-NA, g/d & $2.14 \pm 0.43^{\mathrm{a}}$ & $2.20 \pm 0.30^{\mathrm{a}}$ & $1.58 \pm 0.33^{\mathrm{b}}$ \\
$\mathrm{N}-\mathrm{MP}$, g/d & $10.6 \pm 2.10^{\mathrm{a}}$ & $10.74 \pm 2.60^{\mathrm{a}}$ & $7.69 \pm 1.62^{\mathrm{b}}$ \\
Small intestine & & & \\
$\quad \mathrm{N}-$ digestibility, \% intake & $96.2 \pm 15.5^{\mathrm{a}}$ & $80.8 \pm 19.2^{\mathrm{ab}}$ & $79.5 \pm 10.8^{\mathrm{b}}$ \\
$\mathrm{N}$-absorption, \% inflow & $69.3 \pm 7.5$ & $67.0 \pm 5.6$ & $66.9 \pm 4.7$ \\
\hline
\end{tabular}

$\mathrm{a}, \mathrm{b}-\mathrm{P}<0.05$ 
(1979) observed increased water consumption and dilution rate occurring proportionately to changes in the $\mathrm{pH}$ and increasing rate of VFA evacuation from the rumen.

The $\mathrm{pH}$ of the rumen content was low in all of the sheep and averaged 5.59 in the control group, 5.85 in the calcium and 5.73 in the sodium group (Table 4). A rise in rumen $\mathrm{pH}$ and dilution rate after feeding diets loaded with $\mathrm{Na}$ was observed in bulls by Rogers et al. (1982) and Estell and Gaylean (1985), and in sheep by Thomson et al. (1978).

Calcium lactate as the calcium source in the diet is, in contrast to alkali and calcium buffers, a natural metabolite that is rapidly converted in the rumen to VFA. Loading sheep with $\mathrm{Ca}$ and $\mathrm{Na}$ did not cause any significant changes in the lactic acid and VFA contents, which averaged 3.74 and $117 \mathrm{mmol} / \mathrm{l}$ and in the proportions of $\mathrm{C}_{2}: \mathrm{C}_{3}: \mathrm{C}_{4}$ equalling 56:32:12, respectively (Table 4), typical for rations containing a large proportion of concentrates. Rogers et al. (1982), Wiedemeier et al. (1987) and Erdman (1988) feeding cows with forage found increased $\mathrm{C}_{2}: \mathrm{C}_{3}$ proportion accompanied with higher cellulolytic bacteria activity in the rumen liquor after supplementing diet with $\mathrm{NaHCO}_{3}$. However, increased cellulolytic activity in the rumen liquor is usually met at higher than determined in our experiment $\mathrm{pH}$ value.

Calcium lactate was used in all groups of sheep, in groups I and III for Ca supplementation. In previous studies (Leontowicz et al., 1994) were found negative retention of $\mathrm{Ca}$ in a control group of sheep fed a diet balanced according to ARC requirements (1980), that is why the amount of this element, so important for growing animals, was increased in the current experiment to $5 \mathrm{~g} \mathrm{Ca} / \mathrm{d}$ in the control group.

Despite the loading with $\mathrm{Ca}$ and $\mathrm{Na}, \mathrm{DM}$ duodenal flow was similar in all sheep, and its apparent digestibility in the forestomachs (expressed in absolute terms) was higher in the group loaded with $\mathrm{Na}(\mathrm{P}<0.05)$ than in the control $(280$ vs $192 \mathrm{~g} / \mathrm{d}$ ) (Table 3). The higher digestibility of DM in the forestomachs of sheep loaded with $\mathrm{Na}$ may have been not only the result of greater $\mathrm{Na}$ and $\mathrm{Ca}$ absorption (Leontowicz et al., 1995), but also the somewhat higher digestibility of OM in the forestomachs (Table 3). The apparent digestibility coefficients of DM did not differ significantly among groups and ranged from 29 (I) to $40 \%$ (III) in the forestomachs, while from 22 (II, III) to $28 \%$ (I) in the small intestine. Phillipson (1983), Mess et al. (1985) and Leontowicz et al. (1993) did not find any effect of $\mathrm{Na}$ and/or $\mathrm{Ca}$ (Leontowicz et al., 1994) on the apparent digestibility of $\mathrm{DM}$ or OM.

The sheep received feeds containing similar amounts of nitrogen (17-18 g/day) (Table 5), and the concentration of $\mathrm{NH}_{3}$ in the rumen liquid was low (Table 4). It was higher only in sheep loaded with $\mathrm{Ca}$ as the result of introducing urea $(9 \mathrm{~g} / \mathrm{kg}$ mixture) into the $\mathrm{Ca}$ mixture to compensate the additional energy introduced by 
calcium lactate. The low $\mathrm{NH}_{3}$ concentration may have been related to the slower rate of degradation of extruded feeds in the rumen and their efficient utilization by microorganisms, accompanied by only slight absorption from the forestomachs under conditions of lowered pH (Table 3).

The amount of total $\mathrm{N}$ entering the duodenum, expressed in per cent of intake, did not differ significantly among groups $(P>0.05)$, although in sheep loaded with $\mathrm{Ca}$ and $\mathrm{Na}$ this value was lower than in controls (119 vs 139\%) (Table 5). Increased duodenal $\mathrm{N}$ flow was found by Wanderly et al. (1987) in bulls and by Leontowicz (1991) in sheep fed feeds slowly fermenting in the rumen in comparison with animals receiving a diet with a high proportion of concentrates.

Loading sheep with $\mathrm{Ca}$ did not affect nucleic acid-N flow through the duodenum, while loading with $\mathrm{Na}$ significantly $(\mathrm{P}<0.05)$ lowered the amount entering the duodenum (Table 5) and the ruminal microbial protein synthesis calculated on this basis; in sheep receiving sodium chloride it equaled 7.69 g N-MP/d and was significantly $(\mathrm{P}<0.05)$ lower than in the remaining groups (10.46 (I) and 10.74 (II) $\mathrm{g} \mathrm{N}-\mathrm{MP} / \mathrm{d}$ ). These results did not differ from figures reported by other authors (Czerkawski, 1974; Evans et al., 1975; Leontowicz, 1991). In searching for the cause of reduced protein synthesis in sheep loaded with $\mathrm{Na}$, it can be supposed that a higher dilution rate reduces the extent of ruminal proteolysis and deamination (Reffet and Boiling, 1985), which could lead to a rise in the amount of feed protein digested in the small intestine (Hemsley, 1975).

The depressing effect of $\mathrm{Ca}$ and $\mathrm{Na}$ on apparent digestibility of crude protein in the small intestine is evident: 96,81 and $80 \%$ in groups I, II and III, respectively (Table 5). In contrast, the absorption coefficients of crude protein in the small intestine did not show such differences among groups loaded with $\mathrm{Ca}$ or $\mathrm{Na}(67 \%)$ and the control group $(69 \%)$, similarly as duodenal and ileal $\mathrm{pH}$, which in sheep fed extruded mixtures equaled 3.37 and 7.63 , respectively.

\section{CONCLUSIONS}

Introducing calcium lactate and sodium chloride into the diets of sheep in amounts exceeding by 5 and 10 times the ARC requirements for $\mathrm{Ca}$ and $\mathrm{Na}$ did not have a significant effect on fermentation, apparent digestibility of $\mathrm{OM}$ in the part of the digestive tract from the mouth to the ileum or on absorption of crude protein in the small intestine.

Intake of excessive amounts of $\mathrm{Na}(12 \mathrm{~g} / \mathrm{d})$ in the form of $\mathrm{NaCl}$ lowered ruminal microbial protein synthesis and the apparent digestibility of crude protein in the small intestine. 
The introduction of excess calcium lactate $(19.6 \%)$ and sodium chloride $(8.5 \%)$ into the composition of extruded mixtures for sheep did not significantly change the $\mathrm{pH}$ in the digestive tract; average $\mathrm{pH}$ values of ruminal, duodenal and ileal digesta equaled $5.73,3.37$ and 7.63 , respectively.

\section{REFERENCES}

ARC, 1980. Requirement for protein. In: The Nutrient Requirements of Ruminant Livestock. Agricultural Research Council, pp. 121-180

Chiy P.C., Phillips C.J.C., 1993. Sodium fertilizer application to pasture. 1. Direct and residual effects on pasture production and composition. Grass Forage Sci. 48, 189-202

Czerkawski J.W., 1974. Methods for determining 2-6-diaminopimelic acid and 2-aminoethylophosphonic acid in gut contents. J. Sci. Food Agric. 25, 45-55

Czerkawski J.W., 1976. Chemical composition of microbial matter in the rumen. J. Sci. Food Agric. $27,621-632$

Durand M., Kawashima R., 1980. Influence of minerals in rumen microbial digestion. In: Y.Ruckebush, P.Thivend (Editors), Digestive physiology and metabolism in ruminants. AVI Publishing Comp., Inc. Westport, CT, pp. 375-408

Erdman R.A., 1988. Dietary buffering requirements of the lactating dairy cow: A revicw. J. Dairy Sci. $71,3246-3266$

Estell R.E., Gaylean M.L., 1985. Relationship of rumen fluid dilution rate to rumen fermentation and dietary characterictics of beef steers. J. Anim. Sci. 60, 1061-1071

Evans R.A., Axford R.F.E., 1975. A method for estimating the quantities of microbial and dictary proteins flowing in the duodenal digesta of ruminants. Proc. Nutr. Soc. 34, 65A

Goodrich R.D., Plegge S.D., Garret J.E., llham A., 1985. In: Calcium and Phosphorus in Animal Nutrition, Part 1. National Feed Ingredients Association (NIFA), West Des Moincs, lowa

Gralak M.A., Mahmood S., Barej W., 1994. Rumen degradability of dry matter and crude fibre of irradiated and sodium hydroxide treated straws. Arch. Anim. Nutr. 47, 63-74

Harris B.K., Thomas V.M., Peterson M.K., Kachman S.D., McInerney M.J., 1989. Influence of minerals on rate of digestion and percentage degradable in vitro ncutral detergent fiber. Nutr. Rep. Int. 40, 219-226

Hemsley J.A., 1975. Effect of high intakes of sodium chloride on the utilization of a protein concentratc by sheep. I. Wool growth. Aust. J. Agric. Res. 26, 709-713

Jacobson N.L, Wiggers K.D., Jacobson G.N., 1975. In: NFIA Literature Review on Calcium in Beef and Dairy Nutrition. National Feed Ingredients Association, West Des Moines, lowa

Leontowicz H., 1991. The effect of readily digestible saccharides in the rations for ruminants on the composition and passage of nitrogen compounds into the duodenum and their absorption in the small intestine (in Polish). Treatises and Monographs, Warsaw Agricultural University, ISBN, 144, pp. 1-63

Leontowicz H., Gralak M., Kulasck G., 1993. The effect of potassium loading on some macro and microelements balance in sheep. In: M. Anke, D. Meissner, C.F. Mills (Editors), Trace elements in man and animals. Tema 8, pp. 672-673

Leontowicz H., Gralak M., Leontowicz M., Leśniewska V., 1994. The influence of dietary loading with $\mathrm{Ca}$ and $\mathrm{Na}$ on digestibility, rumen protein synthesis and mineral balance in growing sheep. Scientific Conference on Mineral Elements in Animals Feeding. Poznań Agricultural University, pp. 217-220 
Leontowicz H., Gralak M., Lcontowicz M., Kulasek G., Krzemiński R., I eśniewska V., 1995. The effect of calcium and sodium loading on organic matter digestibility and mineral absorption in sheep. 2. Absorption of minerals. J. Anim . Feed Sci. 4, 311-319

Łukomski M., 1980. Acid-base and ion homeostasis in ruminants fed diets with $\mathrm{NaOH}$-treated straw (in Polish). Ph.D. Thesis. Warsaw Agricultural Universily

Mess D., Merchen N.R., Mitchel C.I., 1985. Effects of sodium bicarbonate on nitrogen balance, bacterial synthesis and sites of nutrient digestion in sheep. J. Anim. Sci. 61, 985-994

Phillipson L.E., 1983. Effect of sodium bicarbonate on utilization and feed intake of lambs. Can. J. Anim. Sci. 63, 613-621

Reffett J.K., Boling J.A., 1985. Nutrient utilization in lambs fed diets high in sodium or potassium. J. Anim. Sci. 61, 1004-1009

Rogers J.A., Davis C.L., Clarke J.H., 1982. Alteration of rumen fermentation, milk fat synthesis, and nutrient utilization with mineral salts in dairy cows. J. Dairy Sci. $65,557-586$

Rogers J.A., Marks B.C., Davis C.L., Clarke J.H., 1979. Alteration of rumen fermentation in steers by increasing rumen dilution rate with mincral salts. J. Dairy Sci. 62, 1599-1605

Ruszczyc Z., 1983. Animals Feeding and Feed Science (in Polish). PWRiL, Warsaw

Schürch A.F., Lloyd L.E., Crampton E.W., 1950. The use of chromic oxide as an index for determing the digestibility of a dict. J. Nutr. 41, 629-636

Thommson D.J., Beever D.E., Lanthan M.J., Sharp M.E., Terry R.A., 1978. The effect of inclusion of mineral salts in the diet on dilution rate, the pattern of rumen fermentation and the composition of rumen microflora. J. Agric. Sci., Camb. 91, 1-7

van Es A.J.H., 1978 Feed evaluation for ruminants. I. The systems in use from May 1977 onwards in the Netherlands. Livest. Prod. Sci. 5, 331-345

Van Soest P.J., 1982. Nutritional Ecology of the Ruminant. 0. \& B. Books, Inc. Corvallis, Oregon

Wanderley R.C., Theurer C.B., Poore M., 1987. Duodenal bacterial and nonbacterial protein supply in steers fed forage and grain diets. J. Anim. Sci. 64, 295-302

Wiedemeier R.D., Arambel M.J., Lamb R.C., Marcinkowski D.P., 1987. Effect of mineral salts, carbachol, and pilocarpine on nutrient digestibility and ruminal characterictics in cattle. J. Dairy Sci. 70, 592-600

Wilson A.D., Dudziński M.L., 1973. Influence of the concentration and volume of saline water on the food intake of sheep, and of their excretion of sodium and water in urine and faeces. Aust. J. Agric. Res. 24, 245-256

Zinn R.A., Owens F.N., 1982. Rapid procedure for quantifying nucleic acid content of digesta. In: F.N. Owens (Editor), Protein requirements for cattle. Oklahoma State University. MP-109, pp. 26-30

Ziolecki A., Kwiatkowska E., 1973. Gas chromatography of $C_{1}$ to $C_{5}$ fatty acids in rumen liquid and fermentation media. J. Chromatogr. 80, 250-256

\section{STRESZCZENIE}

Wplyw nadmiaru wapnia lub sodu w diecie na trawienie składników organicznych i wchłanianie związków mineralnych u owiec 1 . Trawienie w przedżolądkach $\mathbf{i}$ jelicie cienkim

W doświadczeniu przcprowadzonym na owcach z kaniulami do żwacza, dwunastnicy i jelita biodrowego badano wpływ nadmiaru Ca i Na w dawkach (5 i 10 razy więcej niż zapotrzcbowanic wg ARC) na procesy trawienne $w$ żwaczu $\mathrm{i} w$ jelitach. Wprowadzenie $w$ skład ekstrudowanych 
mieszanek mleczanu wapniowego ( $19.6 \%$ ) lub chlorku sodowego $(9.6 \%)$ nic miało istotncgo wpływu na przebieg procesów trawiennych w żwaczu (strawność pozorna substancji organicznej wynosiła w przedżolądkach średnio $40 \%$, w jelitach $61 \%$ oraz wartość pH treści żwacza (5.73), dwunastnicy (3.37) i jelita biodrowego (7.63). Nadmiar $\mathrm{Na} w$ dawce obniżal $(\mathbf{P}<0.05)$ syntezę białka mikroorganizmów w żwaczu (7.69 g N-MP/d) w porównaniu z uzyskaną u owiec kontrolnych i obciązanych Ca (10.46 i $10.74 \mathrm{~g} \mathrm{~N}-\mathrm{MP} / \mathrm{g})$ oraz strawność pozorną N-całkowitego w jelicie cienkim. 